\title{
Studying the Impact of Accruals Quality and Market Risk Premium on Stock return Excess Using Fama-French Three Factor Model
}

\author{
Shima Khajeh Shalaei ${ }^{1} \&$ Seyed Abbas Hashemi ${ }^{2}$ \\ ${ }^{1}$ MSc, Accounting, Department of Management and Accounting, Mobarakeh Branch, Islamic Azad University, \\ Isfahan, Iran \\ ${ }^{2}$ PhD, Assistant Professor, Department of Management and Accounting, Mobarakeh Branch, Islamic Azad \\ University, Isfahan, Iran \\ Correspondence: Shima Khajeh Shalaei, MSc, Accounting, Department of Management and Accounting, \\ Mobarakeh Branch, Islamic Azad University, Isfahan, Iran. E-mail: khajehshima@gmail.com
}

Received: October 17, 2016

Accepted: November 21, 2016

Online Published: February 28, 2017

doi:10.5539/jpl.v10n2p114

URL: https://doi.org/10.5539/jpl.v10n2p114

\begin{abstract}
Determining effective agents in stock return excess behavior (stock risk premium) is one of the key points in investors decision that its benefit and quality of its elements (like accruals) are the impressive factors on stock return excess (stock risk premium) which influence users decision making. Accruals are temporary adjustments that postpone fulfilled cash flows recognition and estimate error degree. Criteria estimating to study these items quality seem necessary because of affecting over future cash flows. Therefore the current study aims to investigate the effect of accruals quality and market risk premium on stock return excess. In order to examine probe hypothesis, we used Fama-French three-factor model that accruals were added to it. For this aim a sample that includes 88 of accepted companies in Tehran stock exchange between 2005 until 2013 was studied. In order to calculate accruals, we used Dechow et al model (1995) utilizing sectional data and to estimate we used Fama-French model (1993) by multivariable regression method and time series data. This study in nature is collateral and in goal is fundamental-experimental. The conclusions show that between accruals quality factors and stock risk premium there is a negative significant relation and between market and stock risk premium there is a positive significant relation. Moreover, the results indicate that among size agent and stock risk premium also between book value to market value ratio factors and stock risk premium there is a negative significant link.
\end{abstract}

Keywords: accruals quality, market return excess (market risk premium), stock return excess (stock risk premium), stock market value to book value ratio, company size

\section{Introduction}

Accounting income and related elements are part of information considered in the decision-making of individuals. Based on accurate approach in the case of earnings fulfillment and costs occurrence we can report the profit. Since in accrual base, incomes and costs identification are not necessarily along with receipt and payment of cash fund and in benefit computation predictions and estimations are used, therefore this question rises that up to what point we can rely on this digit in time of investing decision making. Response to this question finds importance form the point that wrong decision because of inaccurate or insufficient causes unfair source division (Kordestani, 2013).

With regard to the point that profits identification, the base is accrual, the concept of profit quality is proposed. The quality of accounting income expression is applied by financial interpreters to the distinct relation between accounting income and its cash fund turnover (Salehi et al, 2015). Profit quality is important to investors since the current value of a firm and stock value of it depends on future profit current and people expectations from these benefits that based on these expectations they take action to buy or sell firm's shares. Therefore if the quality of these incomes is high, investing risk in such these companies reduces because the investor can have better estimates from future. So this risk reduction increases investing return in such companies. If the income's quality is low, the risk related to investing in these companies raises and as a conclusion the return of these firms declines. According to aforementioned items, accruals role because of its influence in earning is clearly explicit (Hendrickson \& Breda, 2005). 
In order to evaluate accruals, several models were presented. Dechow et al (1995) by making some adjustments in Jones first model, exhibited Jones reformed model for estimating accruals. They emphasize on this point that most past research focused on accruals deliberate manipulating and they knew these manipulations the reason of profit quality reduction. This is while even without intentional manipulations (profit management), company and industry's characteristics can impress accruals quality. Therefore both type of intentional and unintentional conjecture errors results to profit quality diminution. In present study also in order to evaluate accruals quality, we utilized Dechow et al model. There are also many models that examine various factors effect in the firm over stock expected return. There is no model which can directly estimate accruals quality effect on shared return, therefore, the investors and interpreters have tried to use the existing models and enter the accruals quality as a new variable in the model. One of the proposed models in this field is a Fama-French model (1993). In mentioned model, the effect of agents such as market risk premium, company size, and the ratio of book value to firm's stock exchange value on stock risk premium were studied. A company's risk premium is stock return rate the risk-free return rate is deducted from that. In this probe, in order to investigate accruals quality and market risk premium over stock return excess, we utilized from the Fama-French model and entered the accruals quality as an independent variable in that model.

\subsection{Accounting Income and Accrual Accounting Concept}

Accounting income concept is placed at a structural level and has some application practically. At the structural level, accounting income is calculated from the difference between accomplished earnings arising from periodical barters and endured expenses to obtain this earning. Based on this definition we can enumerate 5 characteristics for accounting income:

1) Accounting income is based on a real transaction that the company has accomplished it. Accounting profession uses trading methods to compute profit.

2) Accounting income is calculated based on time period concept and indicates to company's financial performance in a time period.

3) Accounting income is based on revenue recognition principles. Based on this, principle temporal incomes are identified which is integrated income accomplishment cycle and fulfilled trades.

4) In order to calculate accounting income, costs are measured by historical cost. It means that we need to consider historical cost precisely. Therefore profit separation is not because of asset maintenance is not possible.

5) Accounting income is calculated based on matching principle. This principle necessitates that costs identify based on cause and causal relation. In case that no straight causal connection between costs and incomes can be found, costs are shared by systematic allocation method. If the mentioned methods cannot be employed then the costs have to be considered as a period loss (Belokui, 2002).

In accrual accounting, the earnings that are fulfilled in the financial year account are considered however it is possible the earned cash fund is received in later or previous financial years. Costs are also considered in the same financial period account that the obligation has been formed ignoring the time that those obligations and services fund were paid. In this arrangement providing thorough and comprehensive information of an organization to managers' financial performance is executed easily. These features led to the high position of this arrangement application in profit making institutes. According to abridged definitions that were presented in this financial intermediation, we can inference that accrual accounting completely executes properties registration and heeds to whole organization affairs and accidents (Kordestani, 2013).

Accrual accounting uses all accruals, transfer items, and allocation procedures and aims to connect incomes, costs, profits, and losses to a particular period. By this method, it is possible to have a true reflection of organization performance in the specific period instead of listing only a series of cash receipts and payments. Therefore recognition of incomes, costs, profits, and losses also increase and reduction in properties and debts are the essential part of accrual accounting to measure commercial unit performance (accounting standards committee, 1985).

Therefore the main reason of accrual accounting is to help investors to evaluate commercial unit economic performance through a specific period by using some basic accounting principles like income identification and matching. There is some evidence that shows accounting profit which is the result of accrual process in comparison of cash flows provides better information about institute economic performance (Dechow \& Skinner, 2000). Consequently, accrual accounting records create some items under the accruals heading in company financial records which are the base of accrual accounting. Actually, these items remain as system's advantages 
toward other systems (Gol Arz, 2013).

\subsection{Accruals Classification and Concept}

Jones (1991) defines the difference between profit and cash funds obtained from operation as accruals. Actually, accruals are called to items that defer incomes and costs registration or it is possible to introduce accruals as transfers of cash funds to another time. It means that cash funds receipts and payments are recorded correctly in registered accruals and this matter causes that these items display companies economic truths better. Slovan (1996) defined accruals as working assets variation to depreciation expense deduction (Like Healy's definition, 1985) that this description, exactly corresponds to accounting standards committee's definition of operational accruals which is presented in $95^{\text {th }}$ standard as cash flows. Anyway, their definition of accruals did not include non-current operational assets, non-current operational debts, assets, and financial noncash debts.

The order of writing items in balance sheet, based on their liquidity power caused that balance sheet accrual divides to two groups of current and noncurrent, but these categories have been criticized very much.

According to accruals comprehensive classification, we can point to Richardson \& et al research (2005). Their classification for accruals is based on commercial unit activity. Their definition of commercial unit activity is divided into three parts:

1) Current operating activities

2) Noncurrent operating activities

3) Financing activities

Richardson \& et al (2005) believe that accruals were always exposed to personal and subjective judgments of measuring individuals which cause errors and mistakes deliberately or unintentionally in their measuring. Richardson \& et al know this fact because of two reasons:

1) Based on accounting principle, many accruals related to economic benefits cannot be identified and reported (since they are not reliable).

2) The items that are prepared and reported based on accounting principles are mixed with error.

\subsection{Quality of Profit and Earning Evaluation Method}

The quality of profit is a concept that has various facets so the different definition and measuring criteria are proposed for it. Some of the most important definitions are:

Krishnan \& Parsans (2006) reported profit conformity with economic truth, quality of profit. In Lo point of view (2008), a high-quality profit is a profit that the uses methods and accounting estimates in its creation is unbiased. Hodge in 2003 knows the quality of profit the degree of difference between reported net incomes from actual earnings. In Altamuro opinion (2007) profit quality is profitability to anticipate future cash flows. Lougee in 2004 defined a high-quality profit a profit that has more informational content. Scholer asserted profit quality the degree of accruals connection with cash flows (Hasanzadeh et al, 2009).

Profit quality concept is not a defined and fixed subject but it is a relative concept that depends on its relation to notions and viewpoints. Therefore the major question is that how we can solve the faults in profit or in other hand report a profit that makes an evaluation of economic agency possible and shows the ability of profit making. This kind of profit which is called quality of profit has a significant role in economic decisions (Salehi et al 2015).

One of the most important indexes of profit quality evaluation is the level of produced liquidity by the company. To put it in simple words, although we can manipulate the profits but we can manipulate current flows. In fact as the coloration among accounting profit and cash flow increase the quality of profit increases either (Babajani, 2012).

Generally, we have 4 methods to evaluate the quality of profit, but normally we use the connection between accounting profit and cash flow for evaluation of the quality of profit. These four methods are described below:

The methods based on the relation with stock value: in this method connection between various profit amounts and the stock cost is measured by regression. As the modified correlation coefficient increases, variable profit is more related to stock value.

A method based on informational content: in this method relation between price variation and stock return with unexpected levels of profit amounts is measured with the aid of regression. As the modified correlation coefficient approaches to one, it shows the most informational burden of profit. 
A method based on prediction abilities: in this method, the important fact is that the previous amount of profit can predict the future amounts. As the amount of absolute average of prediction error becomes lower that value has more ability to predict.

A method based on economic profit: In this method, mostly the criteria based on asset cost prediction are considered. We inference these values have higher quality in relation to accounting profit. Economic value added criteria is one of the criteria that relies on this method (Dastgir, 2011).

\subsection{Three Factor Models of Fama-French}

After the presentation of the assets properties pricing model, many tests was performed to examine the generalizability power of this model that Black \& et al (1972) tests and Fama \& Macbeth (1973) study can be named as the most important tests. Despite that these research showed there is a linear and positive link between systematic risk and negotiable papers return, further researches proved assured that besides systematic risk caused by a market factor, there are other factors that are in connection with the stock return and by considering them, you can better explain return changes. This fact is the reason of formation and presenting Arbitrage pricing theory by Stephan in 1976. Subsequently, Richard Roll and Ross in 1980 described features and experimental exams. Against pricing model capital assets that only systematic risk factor is considered in them, Arbitrage pricing theory is a multifactor model. Estimated coefficient in this model displays stock return sensitivity or studied portfolio. Although this model extent systematic risk explanation to various factors but it does not give any information about nature of these factors and does not ordain it clearly. Consequently, we can say that recognizing these factors is a challenge by itself in investing theories (Eslami, 2009).

Among one of the most important studies, Fama-French (1992) with abridgement of previous experimental findings and by relying on sectional regression method obtained from Fama \& Macbeth (1973), they studied the relation between Beta variables, company size, market value to book value ratio, financial pyramids and profit ratio to stock price with expected return in USA stock exchange and concluded that systematic risk cannot explain by itself stock return differences and among the studied variables company size and market value to book value variables can describe stock return average difference better. Fama-French believed that company size and market value to book value ratio are connected to systematic patterns in development and relative profit making (it is potentially the main source of risk in market, (Karimi et al, 2014).

However, we can say that the most important multifactor mode, presented in this field is Fama- French three-factor model. This aforesaid model is a follower of the previous study of Fama-French (1992) in which return average and a finance or a basket of securities are stated by means of a three variable linear function named market beta, stock market value, and book value to stock value ratio. Fama \& French by proving that the two latest variables can analyze regression claimed that they can display the effect of these two variables by the formation of two factors named company size and stock market value to book value. In this model market, market values to book value ratio and company size are the three factors that state the expected stock return.

This model was successful in obviation of much return dissimilarity that we could not explain them in the capital assets pricing model. They justified new variables in the mentioned model with this reason that according to research results in 1992 they expected that these two factors which are the agents of risk in a company affect the return (Khamiran, 2013).

\subsection{Quality Impact of Accruals, Market Risk Premium, Book Value \& Size to Stock Market Value on Stock Return Excess (Stock Risk Premium)}

Determining the factors influential on the behavior of stock return excess is one of the key factors in the decision of investors. Stock return excess of a firm is equal to stock return rate minus risk-free output rate. In this regard, the profit and its constituent elements are of factors effective on stock return excess. Accounting profit and its relative components are considered as information considered by people in case of decision making (Salehi et al, 2015).

Also, accruals show economic realities of a firm better. The public interpretation of accruals refers to the items created by bold actions of management to identify and record events. The accepted accounting principles give relative freedom of action to managers about identification time, the amount of income, and costs; the accruals are obtained when managers recognize accounting profit for an over cash amount (Eslami , 2009).

Stock return excess is the 'monthly return surplus of the market basket after subtracting risk-free output rate' during study course. Since investors are looking for returns, thus, they should attend to the quality of accruals and market return excess when estimating their expected stock return excess (stock risk premium) in order to adjust expected return due to the quality of accruals and market return excess. In this way, investors make their 
decision based on the balance between risk and return. According to the assumptions of asset pricing model, investors are risk-averse and prefer the highest return for a specific level of risk. Further, a risk-averse investor expects a proper return instead of risk acceptance. It should be noted that risk acceptance is not an illogic action in such a situation; if the risk is very high, also the return exception will be high. In fact, investors cannot logically expect to gain high return without accepting high risk. Thus, the much higher market risk than risk-free return (market risk premium), the higher would be stock return premium. Therefore, the accruals and market return excess are influential on stock return excess (stock risk premium).

According to what was said, the role of accruals is completely clear due to their impact on profit quality. Therefore, determining a criterion seems necessary for review of quality of such items due to its effectiveness on future cash flows. The components of accruals can be as indicators that determine improvement or decline in performance of a firm. Thus, we are in search of a model capable of meeting the quality of accruals and to predict its impact on stock return excess (Karimi et al, 2014).

Some scholars such as Dechow et al (1995) found that there is a correlation between different components of interest accruals and market return excess and stock return excess (stock risk premium). In their studies, they used information related to profits; from their viewpoint, the accruals available in a firm would help investors to predict cash flows. Low-quality accruals would reduce prediction power of firm's cash flows; thus, the risk of firm's information and stock return excess would increase and these fluctuations in firm's risk would impact on stock return excess. So, they found that quality of accruals and market return excess are among factors influential on stock return excess (Dechow et al, 1995).

In the case of firm size, small firms usually show more reaction to market unreliability; as a result, there is more fluctuation in their stock prices. Having various products, more market share, and possibility of various trade activities, big companies would decrease their trade risks and increase their profitability. Also, these firms reduce the risk of liquidity power of their shares for investors due to having more free floats. Meanwhile, they have more motivation for earning management due to political reasons. Thus, reduce profit volatility risk for their shareholders. Generally, all these factors cause less stock return excess expected by investors from big firms than small ones (Mohamadpur, 2002). The ratio of book value to market price indicates future potential growth of the firm. When it is expected that a firm would grow in the future, then the book value cannot show firm's potential growth and stock return excess due to nature of accrual accounting; but market value is a reliable source to draw future potential growth of the firm. When profit of a firm decreases, the market shows more reaction; as a result of this reaction, the stock price strongly declines which leads to increase in the ratio of book value to market price. In the same way, when a firm reports a significant profit then the market would lead stock prices upward (ratio of book value to market price would decrease). Throughout the time, the overreaction of the market is revealed and price trend is reversed; as a result, there are more returns created for firms having higher book value to price market ratio (Lakonishok et al, 1994).

Therefore, the higher ratio of book value to market value of firms would lead to the higher risk premium. In addition, the ratio of book value to market value shows future potential growth of the market. thus, this ratio relaters to potential opportunities of growth and future development and it is expected that there is a direct (positive) relationship between mentioned ratio and stock return excess; but it is possible to say that investors of Iran stock exchange do not attend enough to growth opportunities and further development of firms (Akbari et al, 2009).

\section{Research Method}

The current research is of correlation type since it investigates the impact of accruals and the market risk premium on stock return excess. Also, it is fundamental- experimental in terms of goal since results of this study would help to improve policies of article 44. In this research, the multivariate regression method, time series, and cross-sectional data are used for data analysis and test of the hypothesis. Also, Fischer and t-student tests are used for the meaningfulness of regression model and coefficients, while Durbin-Watson test is used for the independence of observations. Also, the population of this research includes firms accepted in Tehran stock exchange. The time period of research is from the beginning of 2005 till the end of 2013. Altogether, 88 firms were selected during this period. Table 1 shows descriptive statistics of research variables. 
Table 1. Descriptive statistics of research variables

\begin{tabular}{cccccc}
\hline variable & Symbol of variable & Min & Max & Mean & SD \\
\hline Stock risk premium & $\mathrm{R}_{\mathrm{i}}-\mathrm{R}_{\mathrm{f}}$ & -0.1757 & 0.2307 & 0.0187 & 0.0784 \\
Market risk premium & $\mathrm{R}_{\mathrm{m}}-\mathrm{R}_{\mathrm{f}}$ & -0.1255 & 0.2831 & 0.0142 & 0.0581 \\
Size factor & $\mathrm{SMB}$ & -0.1647 & 0.0889 & -0.0056 & 0.0458 \\
Book value to market value ratio & $\mathrm{HML}$ & -0.2700 & 0.1303 & -0.0114 & 0.0645 \\
accruals quality factor & $\mathrm{AQF}$ & -0.0858 & 0.1034 & 0.0052 & 0.0382 \\
\hline
\end{tabular}

The main indicator is 'average' that indicates balance point and center of distribution; it is also a good indicator to show the centrality of data.

For example, the average of variables 'stock risk premium' and 'quality of accruals' is equal to 0.0187 and 0.0052 , respectively showing that most data are centered around these points. The standard deviation is also one of the most important dispersion parameters and a criterion for deviation of observations from average. The standard deviation of the variable 'stock risk premium' equals to 0.0784 .

In the current research, the model of Fama and French (1993) was used along with the quality of accruals. Since this model is determined by time series, the stability of research variables should be confirmed before using results. In this way, the generalized Dickey-Fuller test is used. Summary of results is shown in table below:

Table 2. Stability test results of research variables

\begin{tabular}{ccccc}
\hline Variable & Symbol of variable & Dickey-Fuller probability statistics & Results & Index \\
\hline Stock risk premium & $\mathrm{R}_{\mathrm{i}}-\mathrm{R}_{\mathrm{f}}$ & 0.000 & Stability of variable & $2-1$ \\
Market risk premium & $\mathrm{R}_{\mathrm{m}}-\mathrm{R}_{\mathrm{f}}$ & & Stability of variable & $2-2$ \\
Size factor & $\mathrm{SMB}$ & 0.000 & Stability of variable & $2-3$ \\
Book value to market value ratio & $\mathrm{HML}$ & 0.000 & Stability of variable & $2-4$ \\
Accruals quality factor & $\mathrm{AQF}$ & 0.000 & Stability of variable & $2-5$ \\
\hline
\end{tabular}

\subsection{Studying the Linearity between Research Variables}

The variance inflation factor test (VIF) is used to study linearity between independent variable. If VIF statistics of variables is lower than 10 , then linearity problem would not exist between independent variables. Table (3) shows summary of test results:

Table 3. Linearity test results between independent variables of research

\begin{tabular}{cccc}
\hline variable & Symbol of variable & VIF statistics & Results \\
\hline Market risk premium & $\mathrm{R}_{\mathrm{m}}-\mathrm{R}_{\mathrm{f}}$ & 1.059 & Non-linearity \\
Size factor & $\mathrm{SMB}$ & 1.403 & Non-linearity \\
Book value to market value ratio & $\mathrm{HML}$ & 1.543 & Non-linearity \\
Accruals quality factor & $\mathrm{AQF}$ & 1.169 & Non-linearity \\
\hline
\end{tabular}

Next, the results of Fama and French estimation model (1993) are briefly presented and analyzed in the table below. 
Table 4. Results of Fama and French estimation model

\begin{tabular}{ccccc}
\hline \multicolumn{4}{c}{$\mathrm{R}_{\mathrm{i}, \mathrm{t}}-\mathrm{R}_{\mathrm{f}, \mathrm{t}}=\alpha_{\mathrm{i}}+\beta_{\mathrm{i}}\left(\mathrm{R}_{\mathrm{m}, \mathrm{t}}-\mathrm{R}_{\mathrm{f}, \mathrm{t}}\right)+\mathrm{S}_{\mathrm{i}}\left(\mathrm{SMB}_{\mathrm{t}}\right)+\mathrm{h}_{\mathrm{i}}\left(\mathrm{HML}_{\mathrm{t}}\right)+\mathrm{e}_{\mathrm{i}}\left(\mathrm{AQF}_{\mathrm{t}}\right)+\boldsymbol{\varepsilon}_{\mathrm{i}, \mathrm{t}}$} \\
\hline Variable & Symbol of variable & Ratio & t-statistics & Possibility of t-statistics \\
Intercept & $\alpha i$ & 0.0006 & 0.1165 & 0.9075 \\
Market risk premium & $\mathrm{Rm}-\mathrm{Rf}$ & 0.7423 & 7.5482 & 0.0000 \\
Size factor & $\mathrm{SMB}$ & -0.9252 & -6.4446 & 0.0000 \\
Book value to market value ratio & $\mathrm{HML}$ & -0.3382 & -3.1641 & 0.0021 \\
Accruals quality factor & $\mathrm{AQF}$ & -0.3188 & -2.0287 & 0.0454 \\
Adjusted determination factor & 0.5235 & F-statistics & 27.095 \\
Durbin-Watson statistics & 1.6451 & Possibility of F-statistics & 0.0000 \\
\hline
\end{tabular}

\section{Results}

According to H1, quality of accruals is influential on firms' stock excess return (stock risk premium).

The significance of ratio of AQF (ei) at the significance level 95\% indicates a significant impact of AQF on stock risk premium. To check meaningfulness of $\mathrm{AQF}$, the t-statistics is used at an error level of $\alpha=0.05$. According to table (4), it is observed that ei $=-0.3188$ and t-statistics is lower than 0.05 , thus, it is statistically meaningful. The negativity of the mentioned ratio shows that $\mathrm{AQF}$ has negative and meaningful impact on stock risk premium. Therefore, the first research hypothesis is accepted.

According to H2, the market return excess is influential on firms' stock risk premium.

The significance of the variable market risk premium $(\beta i)$ at the significance level $95 \%$ indicates significant impact of MRP on stock risk premium. According to table (4), it is observed that $\beta i=0.7423$ and t-statistics is lower than 0.05 , thus, it is statistically meaningful. Therefore, market risk premium has positive and meaningful impact on stock risk premium and the second research hypothesis is accepted.

According to H3, firm size factor is influential on firms' stock risk premium.

The significance of the variable firm size ( $\mathrm{S} i$ ) at the significance level $95 \%$ indicates significant impact of size factor on stock risk premium. According to table (4), it is observed that $S i=-0.9252$ and t-statistics is lower than 0.05 , thus, it is statistically meaningful. The negativity of the mentioned ratio shows that size factor has negative and meaningful impact on stock risk premium. As a result, the third research hypothesis is accepted.

According to H4, book value to market value ratio is influential on firms' stock risk premium.

The significance of book value to market value ratio (hi) at the significance level $95 \%$ indicates significant impact of this factor on stock risk premium. According to table (4), it is observed that $h i=-0.3382$ and t-statistics is lower than 0.05 , thus, it is statistically meaningful. The negativity of this factor shows that book value to market value ratio has negative and meaningful impact on stock risk premium. As a result, the fourth research hypothesis is accepted.

\section{Discussion}

It is perceived that managers who present $\mathrm{AQF}$, i.e. higher profit quality of the firm- would, in fact, provide more information about the firm for investors; this causes information clarity for investors since information disclosure has loading content. This leads to more attraction of such shares for investors and increase of demand for them following a decrease in stock return. In relation to the impact of size factor on stock risk premium, it is possible to say that firm's size factor has a meaningful impact on stock risk premium when established portfolios include a share of small firms and also large ones. On the other hand, lack of positive conformity and impact on theoretical principles is that firms with a high ratio of book value to market value would have weaker performance and perhaps higher risk. Thus, these firms expect higher returns. The poor previous performance of firms with a high ratio of book value to market value indicates their improper financial status.

\section{References}

Akbari Moghaddam, B., Rezaee, F., \& Norouzi, A. (2009). Comparing the predictive power of Fama \&French model with Beta value and expected returns on stock. Quarterly Journal of economic modeling, 3(1), 55-75.

Babajani, J., \& Azimi Yancheshme, M. (2012). The reliability effect of accruals on stock returns. journal of 
research in financial accounting, 4(2), 83-100.

Dastgir, M. (2011). Studying the relationship between profit quality, size of accruals and stock return and AQF. quarterly of accounting research, 7, 1-20.

Dechow, P. M., Kothari, S. P., \& Watts, R. L. (1998). The relation between earnings and cash flows. Journal of accounting and Economics, 25(2), 133-168. http://dx.doi.org/10.1016/s0165-4101(98)00020-2

Dechow, P. M., Sloan, R. G., \& Sweeney, A. P. (1995). Detecting earnings management. Accounting review, 193-225. http://dx.doi.org/10.1111/j.1475-679x.2012.00449.x

Eslami, Gh. (2009). Improving the expected explanation of Fama \& French three-factor model using capital efficiency. journal of accounting research, 50-73.

Fama, E. F., \& French, K. R. (1992). The cross - section of expected stock returns. the Journal of Finance, 47(2), 427-465. http://dx.doi.org/10.1111/j.1540-6261.1992.tb04398.x

Fama, E. F., \& French, K. R. (1993). Common risk factors in the returns on stocks and bonds. Journal of financial economics, 33(1), 3-56. http://dx.doi.org/10.1016/0304-405x(93)90023-5

Gol Arzi, Gh. (2013). Studying the relationship between stock return and profit quality by mediation of institutional ownership of firms listed in Tehran stock exchange. quarterly of accounting and auditing, 65-86.

Hasanzadeh, R., Badavar Nahandi, Y., \& Pourrabbi, M. V. (2009). Quality assessment of the profitability of companies listed in Tehran Stock Exchange. Quarterly Journal of financial accounting, 1(2), 144-158.

Healy, P. M., \& Wahlen, J. M. (1999). A review of the earnings management literature and its implications for standard setting. Accounting horizons, 13(4), 365-383. http://dx.doi.org/10.2308/acch.1999.13.4.365

Hendrickson, H., \& Williams, P. (Eds.). (2004). Accounting Theory. Routledge New Works in Accounting History. http://dx.doi.org/10.4324/9780203409053

Karimi, M. (2014). Studying the relationship between liquidity and market risk and unusual return in Fama \& French three-factor model: case study of Tehran stock exchange. journal of finance engineering and management of securities, 20, 149-164.

Khamiran, M. (2013). The impact of systematic risk on the stock return of medical and chemical firms using wavelet analysis: a case study of Tehran stock exchange', MA thesis, University of Tehran.

Kordestani, Gh. (2013). Comparison of excess return portfolios based on traditional and relative accruals, 101-122.

Lakonishok, J., Shleifer, A., \& Vishny, R. W. (1994). Contrarian investment, extrapolation, and risk. The journal of finance, 49(5), 1541-1578. http://dx.doi.org/10.1111/j.1540-6261.1994.tb04772.x

Mohamadpour, H. (2012). Studying the strategic impact of lack of liquidity risk, size and ratio of book value to market value on stock return excess of stock exchange. Quarterly of investment knowledge, 3, 1-16.

Salehi, M., Vaghfi, H., \& Rajabzadeh, A. A. (2014). The quality impact of optional obligations on stock risk. research on accounting and auditing, 20, 72-89.

\section{Copyrights}

Copyright for this article is retained by the author(s), with first publication rights granted to the journal.

This is an open-access article distributed under the terms and conditions of the Creative Commons Attribution license (http://creativecommons.org/licenses/by/4.0/). 